\title{
Dietary, physical exercises and mental stress in a Chinese population: a cross- sectional study
}

Xiaona $\mathrm{Li}^{1,2+}$, Dan Tian ${ }^{3 \dagger}$, Pei Qin ${ }^{1}$, Wen Guo ${ }^{1}$, Jing Lu', Wenfang Zhu', Qun Zhang ${ }^{1,2^{*}}$ and Jianming Wang ${ }^{2,3^{*}}$

\begin{abstract}
Background: Mental health is affected by both genetic and environmental factors. However, previous studies have showed conflict findings about the role of lifestyle and little is known about the situation of the Chinese population. The purpose of this study was to explore the relationship between the frequency of food consumption, physical exercise condition and mental health, as well as factors related to mental stress in Chinese.

Methods: We recruited 8160 residents who had health examinations in a public hospital during June 2016 to May 2018. Demographic characteristics, the frequency of food consumption, physical exercise condition and mental health status was collected by a questionnaire. We estimated the association using the odds ratio (OR) and 95\% confidence interval (CI) based on Binary or ordinal logistic regression models. A classification and regression tree (CART) demonstrated the prediction of the value of a target variable based on other values.

Results: The logistic regression model and classification tree model both found that the frequency of fresh vegetables or fruit and fried foods consumption and the current state of drinking alcohol were related to mental stress. The degree of mental stress reduced significantly with increasing consumption of fish $(\mathrm{OR}=0.80,95 \% \mathrm{Cl}$ : $0.71-0.90)$ and regular exercise $(\mathrm{OR}=0.55,95 \% \mathrm{Cl}: 0.48-0.64)$ in females and increased consumption of fish $(\mathrm{OR}=$ $0.55,95 \% \mathrm{Cl}: 0.48-0.64)$ and cereal crop $(\mathrm{OR}=0.77,95 \% \mathrm{Cl}: 0.68-0.89)$, fish $(\mathrm{OR}=0.87,95 \% \mathrm{Cl}: 0.77-0.96)$ and regular exercise $(\mathrm{OR}=0.61,95 \% \mathrm{Cl}: 0.53-0.70)$ in males. On the contrary, the frequency of consumption of desserts $(\mathrm{OR}=$ $1.43,95 \% \mathrm{Cl}: 1.26-1.62)$ and the current of drinking alcohol $(\mathrm{OR}=1.47,95 \% \mathrm{Cl}: 1.21-1.79)$ in females and meat $(\mathrm{OR}=$ $1.47,95 \% \mathrm{Cl}: 1.31-1.65)$, pickled and smoked food $(\mathrm{OR}=1.18,95 \% \mathrm{Cl}: 1.05-1.32)$ and the current state of drinking alcohol $(\mathrm{OR}=1.25,95 \% \mathrm{Cl}: 1.12-1.40)$ in males were related to an increased risk of mental health.
\end{abstract}

Conclusions: Our study showed that both the frequency of some food consumption and physical exercise condition were associated with mental health and affected the degree of stress, which provided novel insights into interventions.

Keywords: Stress, Mental health, Food frequency, Food consumption, Exercise

\footnotetext{
* Correspondence: lucyqzhang@126.com; jmwang@njmu.edu.cn

'Xiaona Li and Dan Tian contributed equally to this work.

'Health Management Center, The First Affiliated Hospital with Nanjing Medical University, Nanjing 210029, China

${ }^{2}$ Department of Health Management, School of Public Health, Center for Global Health, Nanjing Medical University, Nanjing 211166, China Full list of author information is available at the end of the article
}

(c) The Author(s). 2021 Open Access This article is licensed under a Creative Commons Attribution 4.0 International License, which permits use, sharing, adaptation, distribution and reproduction in any medium or format, as long as you give appropriate credit to the original author(s) and the source, provide a link to the Creative Commons licence, and indicate if changes were made. The images or other third party material in this article are included in the article's Creative Commons licence, unless indicated otherwise in a credit line to the material. If material is not included in the article's Creative Commons licence and your intended use is not permitted by statutory regulation or exceeds the permitted use, you will need to obtain permission directly from the copyright holder. To view a copy of this licence, visit http://creativecommons.org/licenses/by/4.0/. The Creative Commons Public Domain Dedication waiver (http://creativecommons.org/publicdomain/zero/1.0/) applies to the data made available in this article, unless otherwise stated in a credit line to the data. 


\section{Introduction}

Mental stress refers to the psychological confusion or threat caused by various irritating events and adverse factors in daily life. Mental stress is strongly linked to our health both physically and mentally $[1,2]$. Moderate stress has substantial, favorable effects on individual's work or study, while chronic excessive stress may trigger severe fatigue, exhaustion even psychological disorders [3-5]. As the pace of modern life is speeding up, the negative impact of mental stress on health has gained much more attention [6, 7]. According to the World Health Organization, a quarter of people suffer from the mental stress in the world and which has been regarded as a health burden that should be highly valued $[8,9]$. Despite the fact that there is no an extraordinary solution at hand to entirely avoid mental stress, people try to abate and prevent it through therapy or external intervention. And several randomized clinical trials have found that meditation programs, yoga exercise and spa therapy may reduce the adverse effects of mental stress to some extent [10-12]. Given the economic burden that these measures may create, daily diet and physical exercises could be more operable tools in reducing mental stress currently.

There is a growing body of evidences that lifestyle factors, especially diet, have beneficial effects on mental stress. Scrieks et al. observed that drinking a moderate amount of alcohol might promote the recovery of endocrine stress response [13]. Yoshikawa et al. reported a significant positive correlation between the frequency of fried food consumption and depressive symptoms among the Japanese population [14]. Furthermore, it has been found that increased intake of fruit and vegetables may help to reduce psychological pain in a follow-up study of psychological distress among middle-aged and elderly Australians [15]. Besides, moderate-intensity exercises are proved to decrease tumor necrosis factoralpha and improve mental health [16]. However, little is known about the relationship between mental stress and the frequency of food consumption and physical exercise condition in Chinese population.

Considering the important role of diet and exercise on mental stress, the purpose of this study was to explore the relationship between the frequency of food consumption, physical exercise condition and self-reported mental health in a Chinese population and to identify factors related to mental stress for future interventions.

\section{Materials and methods}

\section{Participants and procedures}

Participant data were used from a dataset containing the baseline information of 8160 people who took part in a routine health examination at the Health Management Center of the First Affiliated Hospital of Nanjing
Medical University during June 2016 and May 2018. In the center, all subjects must accomplish a baseline health status survey questionnaire before checkup through the WeChat platform under the instructions of specialized medical staff. The initial purpose of the baseline questionnaire is to help medical staff understand the health status and living habits of the examinee, so as to better recommend physical examination items for them. It consists of 31 items concerning demography, present symptoms, history of disease and medication, family history of illness, health behavior issues and self-reported mental stress.

However, the questions pertaining to self-rated health and mental stresses were the focus of the analysis. A total of 18 items were used in the analysis at last. (1) For diet, we collected the frequency of cereal crops, meat, fish or other aquatic products, fresh vegetables or fruits, milk or dairy products, eggs, beans, desserts, fried foods, pickled or smoked foods, and nuts consumption (days per week). (2) In terms of physical exercise, variables include frequency (days per week), exercise duration (time per day). Refer to the American College of Sports Medicine's Guidelines for Exercise Testing and Prescription (10th ed), at least $30 \mathrm{~min}$ of moderate-intensity (distinguished by sweating or not during the exercise) physical activity per for 3 times per week was defined as "regular exercise". (3) The smoking situation was divided into smoking (at least 1 cigarette per day in the past year), former smoking (quit smoking for more than 6 months), and non-smoking. (4) Drinkers were referred to those who drink $\geq 1$ time a month, and at least 1 cup each time (1 cup contains $10 \mathrm{~g}$ of ethanol, such as $20 \mathrm{~mL}$ wine, $300 \mathrm{~mL}$ beer, $100 \mathrm{~mL}$ red wine). Non-drinkers were those who drink $<1$ time per month. For drinkers, the average daily alcohol intake was calculated by the average use of wine, beer, red wine per time and the frequency (times per week). (5) To describe the mental health, participants indicated their degree of stress in life or work during the last 12 months from four categories"not at all", "mild", "moderate", and "intense".

\section{Statistical analysis}

We performed statistical analyses using SPSS 25 software. Continuous variables were described as the mean and standard deviation (SD), if does not conform to the normal distribution and with uneven variance they were described by the median method. Categorical variables were expressed in percentages and constituent ratios. The logistic regression model is insufficient to deal with the collinearity of variables, while the CART is not affected by the collinearity problems among variables in the analysis. The binary logistic regression model and classification and regression tree (CART) model were used to analyze factors related to mental stress. Both 
Table 1 Binary logistic regression analysis of the generation of mental stress on female

\begin{tabular}{|c|c|c|c|c|c|c|}
\hline \multirow[t]{2}{*}{ Terms } & \multicolumn{2}{|c|}{ Mental stress, n (\%) } & \multirow[t]{2}{*}{ Z } & \multirow[t]{2}{*}{$P$} & \multirow{2}{*}{$\begin{array}{l}\text { Adjusted OR } \\
(95 \% \mathrm{Cl})^{*}\end{array}$} & \multirow[t]{2}{*}{$P^{*}$} \\
\hline & No & Yes & & & & \\
\hline \multicolumn{7}{|c|}{ Cereal crop (day/week) } \\
\hline $0-4$ & 129 & 712 & 23.34 & $<0.01$ & 1 & 0.17 \\
\hline $5-7$ & 648 & 2155 & & & $0.85(0.68-1.07)$ & \\
\hline \multicolumn{7}{|l|}{ Meat (day/week) } \\
\hline $0-4$ & 475 & 1761 & 0.02 & 0.88 & - & - \\
\hline $5-7$ & 302 & 1106 & & & & \\
\hline \multicolumn{7}{|c|}{ Fresh vegetables or fruits (day/week) } \\
\hline $0-4$ & 168 & 1028 & 56.18 & $<0.01$ & 1 & $<0.01$ \\
\hline $5-7$ & 609 & 1839 & & & $0.71(0.57-0.87)$ & \\
\hline \multicolumn{7}{|c|}{ Fish or aquatic products (day/week) } \\
\hline $0-2$ & 431 & 1781 & 11.34 & $<0.01$ & 1 & 0.01 \\
\hline $2-7$ & 346 & 1086 & & & $0.80(0.67-0.95)$ & \\
\hline \multicolumn{7}{|c|}{ Milk or dairy products (day/week) } \\
\hline$<1$ & 325 & 970 & 17.05 & $<0.01$ & 1 & 0.11 \\
\hline $1-7$ & 452 & 1897 & & & $1.16(0.97-1.39)$ & \\
\hline \multicolumn{7}{|c|}{ Eggs or their products (day/week) } \\
\hline $0-2$ & 217 & 938 & 6.48 & 0.01 & 1 & 0.21 \\
\hline $3-7$ & 560 & 1929 & & & $0.88(0.72-1.07)$ & \\
\hline \multicolumn{7}{|c|}{ Legumes or their products (day/week) } \\
\hline $0-2$ & 426 & 1677 & 3.37 & 0.07 & 1 & 0.92 \\
\hline $3-7$ & 351 & 1190 & & & $1.01(0.85-1.21)$ & \\
\hline \multicolumn{7}{|l|}{ Dessert (day/week) } \\
\hline$<1$ & 374 & 1051 & 33.81 & $<0.01$ & 1 & 0.38 \\
\hline $1-7$ & 403 & 1816 & & & $1.08(0.90-1.30)$ & \\
\hline \multicolumn{7}{|l|}{ Fried food (day/week) } \\
\hline$<1$ & 577 & 1649 & 72.10 & $<0.01$ & 1 & $<0.01$ \\
\hline $1-7$ & 200 & 1218 & & & $1.41(1.14-1.72)$ & \\
\hline \multicolumn{7}{|c|}{ Pickled or smoked food (day/week) } \\
\hline$<1$ & 482 & 1684 & 2.76 & 0.09 & 1 & 0.68 \\
\hline $1-7$ & 295 & 1183 & & & $1.04(0.87-1.25)$ & \\
\hline \multicolumn{7}{|l|}{ Nuts (day/week) } \\
\hline$<1$ & 365 & 1324 & 0.39 & 0.82 & - & - \\
\hline $1-7$ & 353 & 1307 & & & & \\
\hline \multicolumn{7}{|l|}{ Regular exercise } \\
\hline No & 538 & 2333 & 54.14 & $<0.01$ & 1 & $<0.01$ \\
\hline Yes & 239 & 533 & & & $0.64(0.53-0.77)$ & \\
\hline \multicolumn{7}{|l|}{ Marital status } \\
\hline Unmarried/single & 48 & 524 & 67.63 & $<0.01$ & 1 & $<0.01$ \\
\hline Married & 729 & 2343 & & & $0.57(0.41-0.79)$ & \\
\hline \multicolumn{7}{|l|}{ Age (years) } \\
\hline$\leq 43$ & 201 & 1618 & 228.47 & $<0.01$ & 1 & $<0.01$ \\
\hline$>43$ & 576 & 1249 & & & $0.37(0.30-0.44)$ & \\
\hline
\end{tabular}

Smoking 
Table 1 Binary logistic regression analysis of the generation of mental stress on female (Continued)

\begin{tabular}{|c|c|c|c|c|c|c|}
\hline \multirow[t]{2}{*}{ Terms } & \multicolumn{2}{|c|}{ Mental stress, n (\%) } & \multirow[t]{2}{*}{ Z } & \multirow[t]{2}{*}{$P$} & \multirow{2}{*}{$\begin{array}{l}\text { Adjusted OR } \\
(95 \% \mathrm{Cl})^{*}\end{array}$} & \multirow[t]{2}{*}{$P^{*}$} \\
\hline & No & Yes & & & & \\
\hline None/Former & 763 & 2797 & 1.11 & 0.29 & 1 & 0.32 \\
\hline Current & 14 & 70 & & & $0.73(0.39-1.36)$ & \\
\hline \multicolumn{7}{|l|}{ Drinking alcohol } \\
\hline None/Former & 716 & 2541 & 7.98 & $<0.01$ & 1 & 0.12 \\
\hline Current & 61 & 326 & & & $1.27(0.94-1.73)$ & \\
\hline
\end{tabular}

*: Adjusted for marital status, age, smoking, drinking alcohol and other variables which were significant in the univariate analysis

models took the existence of mental stress $(1=$ yes, $0=$ no) as the dependent variable. The CART model was established by chi-squared automatic interaction detector (CHAID). The minimum sample size of parent node and child node was 100 and 50 respectively, and the maximum number of growth layers of the tree is 3 layers. Then, we explored the main influencing factors of mental stress by establishing the ordered logistic model. All significance tests were double-tailed, and the difference was statistically significant if $P<0.05$.

\section{Results}

After excluding 13 people with missing data on the dietary condition, 8147 subjects were included in the analysis. Ages ranged from 18 to 87 . The average age was $43.1 \pm 0.1$ years. The ratio of male to female was $1.24: 1$, and the majority were married ( $n=6751,82.9 \%)$. The proportion of participants reporting mild, moderate, and intense stress was $17.7,35.3$, and $30.0 \%$, respectively.

\section{Binary logistic regression analysis on factors related to mental stress}

The binary logistic regression model was adjusted for age, marital status, smoking status and drinking alcohol circumstance. Analyses were stratified by gender groups. As shown in Table 1 and Supplementary Table 2, increased frequency of fresh vegetables or fruits $(\mathrm{OR}=$ 0.71, 95\% CI: 0.57-0.87), fish (OR = 0.80, 95\% CI: 0.67$0.95)$ consumption and regular exercise $(\mathrm{OR}=0.64,95 \%$ CI: 0.53-0.77) reduced the risk of mental stress. Contrarily, the higher frequency of fried foods $(\mathrm{OR}=1.41$, 95\% CI: 1.14-1.72) intake increased the risk of mental stress. The situation of fresh vegetables or fruit consumption $(\mathrm{OR}=0.71,95 \% \mathrm{CI}: 0.58-0.87)$, fish $(\mathrm{OR}=0.83$, 95\% CI: 0.69-0.99) consumption, and regular exercise $(\mathrm{OR}=0.73$, 95\% CI: 0.59-0.90) in male were roughly parallel to female apart from meat $(\mathrm{OR}=1.26,95 \% \mathrm{CI}$ : 1.05-1.52) and milk (OR $=1.45,95 \% \mathrm{CI}: 1.20-1.75)$ consumption (Table 2).

\section{CART analysis}

We used the CART method to explore the role of different factors in the risk of mental stress. A total of 5 variables were included in the final model, including age, marital status, the state of drinking alcohol, the consumption of fresh vegetables or fruits, and fried foods (Fig. 1). The probability of correctly predicting the mental stress was $83.0 \%$. The first node is age, followed by the consumption of fresh vegetables or fruit and fried foods.

\section{Ordinal logistic regression analysis}

We further performed an ordinal logistic regression model to explore factors related to the grade of mental stress stratified by gender. We first conducted a parallel line test, and then variables meeting the hypothesis were further analyzed in adjusted model. As shown in Fig. 2, for females, consumption of dessert 3-7 days per week $(\mathrm{OR}=1.43$, 95\% CI: $1.26-1.62)$ and the current state of drinking alcohol $(\mathrm{OR}=1.47,95 \% \mathrm{CI}: 1.21-1.79)$ were related to an increased risk of mental health; the consumption of fish 3-7 days per week $(\mathrm{OR}=0.80,95 \% \mathrm{CI}$ : 0.71-0.90), eggs (OR $=0.87,95 \% \mathrm{CI}: 0.76-1.00)$ and regular exercise $(\mathrm{OR}=0.55,95 \% \mathrm{CI}$ : 0.48-0.64) decreased the risk of mental stress. For males, the increased frequency of cereal crops $(\mathrm{OR}=0.77,95 \% \mathrm{CI}$ : 0.68-0.89) and fish $(\mathrm{OR}=0.87,95 \% \mathrm{CI}: 0.77-0.98)$ consumption and regular exercise $(\mathrm{OR}=0.61,95 \% \mathrm{CI}: 0.53-0.70)$ contributed to a reduced risk of mental stress, while consumption of meat 5-7 days per week (OR $=1.47,95 \% \mathrm{CI}$ : $1.34-1.65)$ and picked or smoked food 2-7 days per week (OR = 1.18, 95\% CI: 1.05-1.32) and the current state of drinking alcohol $(\mathrm{OR}=1.25,95 \% \mathrm{CI}: 1.12-1.40)$ could increase the degree of mental stress.

\section{Discussion}

Psychological stress has a deleterious effect on a wide range of physical and mental health outcomes with accumulating evidence that health practices/maladaptive behaviors may mediate these relationships [17]. Considering the gender difference has been reported in lots of previous studies about the mental stress-related factors in which the stress level of women had significantly higher than that of men [18, 19], we conducted analysis after adjusting the covariate factors according to gender. The logistic regression model and classification 
Table 2 Binary logistic regression analysis of the generation of mental stress on male

\begin{tabular}{|c|c|c|c|c|c|c|}
\hline \multirow[t]{2}{*}{ Terms } & \multicolumn{2}{|c|}{ Mental stress, n (\%) } & \multirow[t]{2}{*}{ Z } & \multirow[t]{2}{*}{$P$} & \multirow{2}{*}{$\begin{array}{l}\text { Adjusted OR } \\
(95 \% \mathrm{CI})^{*}\end{array}$} & \multirow[t]{2}{*}{$P^{*}$} \\
\hline & No & Yes & & & & \\
\hline \multicolumn{7}{|c|}{ Cereal crop (day/week) } \\
\hline $0-4$ & 121 & 924 & 4.22 & 0.04 & 1 & 0.88 \\
\hline $5-7$ & 486 & 2972 & & & $1.02(0.81-1.29)$ & \\
\hline \multicolumn{7}{|l|}{ Meat (day/week) } \\
\hline $0-4$ & 354 & 1943 & 15.00 & $<0.01$ & 1 & 0.01 \\
\hline $5-7$ & 253 & 1953 & & & $1.26(1.05-1.52)$ & \\
\hline \multicolumn{7}{|c|}{ Fresh vegetables or fruits (day/week) } \\
\hline $0-4$ & 212 & 1887 & 38.51 & $<0.01$ & 1 & $<0.01$ \\
\hline $5-7$ & 395 & 2009 & & & $0.71(0.58-0.87)$ & \\
\hline \multicolumn{7}{|c|}{ Fish or aquatic products (day/week) } \\
\hline $0-2$ & 307 & 2182 & 6.26 & 0.01 & 1 & 0.04 \\
\hline $3-7$ & 300 & 1714 & & & $0.83(0.69-0.99)$ & \\
\hline \multicolumn{7}{|c|}{ Milk or dairy products (day/week) } \\
\hline$<1$ & 346 & 1682 & 40.58 & $<0.01$ & 1 & $<0.01$ \\
\hline $1-7$ & 261 & 2214 & & & $1.45(1.20-1.75)$ & \\
\hline \multicolumn{7}{|c|}{ Eggs or their products (day/week) } \\
\hline $0-2$ & 235 & 1406 & 1.56 & 0.21 & - & - \\
\hline $3-7$ & 372 & 2490 & & & & \\
\hline \multicolumn{7}{|c|}{ Legumes or their products (day/week) } \\
\hline $0-2$ & 326 & 2160 & 0.64 & 0.42 & - & - \\
\hline $3-7$ & 281 & 1736 & & & & \\
\hline \multicolumn{7}{|l|}{ Dessert (day/week) } \\
\hline$<1$ & 339 & 1796 & 20.02 & $<0.01$ & 1 & 0.67 \\
\hline $1-7$ & 268 & 2100 & & & $1.04(0.86-1.27)$ & \\
\hline \multicolumn{7}{|c|}{ Fried food (day/week) } \\
\hline$<1$ & 405 & 1990 & 51.62 & $<0.01$ & 1 & 0.07 \\
\hline $1-7$ & 202 & 1906 & & & $1.22(0.98-1.50)$ & \\
\hline \multicolumn{7}{|c|}{ Pickled or smoked food (day/week) } \\
\hline$<1$ & 364 & 2018 & 14.07 & $<0.01$ & 1 & 0.09 \\
\hline $1-7$ & 243 & 1878 & & & $1.18(0.97-1.43)$ & \\
\hline \multicolumn{7}{|l|}{ Nuts (day/week) } \\
\hline$<1$ & 310 & 1876 & 2.28 & 0.32 & - & - \\
\hline $1-7$ & 263 & 1759 & & & & \\
\hline \multicolumn{7}{|l|}{ Regular exercise } \\
\hline No & 436 & 3151 & 9.62 & $<0.01$ & 1 & $<0.01$ \\
\hline Yes & 171 & 745 & & & $0.73(0.59-0.90)$ & \\
\hline \multicolumn{7}{|l|}{ Marital status } \\
\hline Unmarried/single & 52 & 772 & 26.54 & $<0.01$ & 1 & \\
\hline Married & 555 & 3124 & & & $0.63(0.46-0.85)$ & $<0.01$ \\
\hline \multicolumn{7}{|l|}{ Age (years) } \\
\hline$\leq 43$ & 150 & 2140 & 191.86 & $<0.01$ & 1 & \\
\hline$>43$ & 457 & 1756 & & & $0.36(0.29-0.45)$ & $<0.01$ \\
\hline
\end{tabular}

Smoking 
Table 2 Binary logistic regression analysis of the generation of mental stress on male (Continued)

\begin{tabular}{|c|c|c|c|c|c|c|}
\hline \multirow[t]{2}{*}{ Terms } & \multicolumn{2}{|c|}{ Mental stress, n (\%) } & \multirow[t]{2}{*}{ Z } & \multirow[t]{2}{*}{$P$} & \multirow{2}{*}{$\begin{array}{l}\text { Adjusted OR } \\
(95 \% \mathrm{CI})^{*}\end{array}$} & \multirow[t]{2}{*}{$P^{*}$} \\
\hline & No & Yes & & & & \\
\hline None/Former & 351 & 2390 & 2.73 & 0.09 & 1 & 0.06 \\
\hline Current & 256 & 1506 & & & $0.84(0.70-1.01)$ & \\
\hline \multicolumn{7}{|l|}{ Drinking alcohol } \\
\hline None/Former & 291 & 1793 & 0.78 & 0.38 & 1 & 0.01 \\
\hline Current & 316 & 2103 & & & $1.26(1.05-1.52)$ & \\
\hline
\end{tabular}

*: Adjusted for marital status, age, smoking, drinking alcohol and other variables which were significant in the univariate analysis

tree model both reveal that higher consumption of fresh vegetables or fruit were associated with lower levels of mental stress. This finding is broadly consistent with many previous researches [20-23]. The protective effect of vegetables and fruit against mental stress may attribute to their plentiful antioxidant substances, which can reduce the oxidative stress and thus relieve damage to the components of neural cell [24]. Besides, the high dietary fiber intake might be link to better mental health by influencing gut microbiota [25].

In addition, mounting evidences demonstrated that fish consumption (rich in omega-3 polyunsaturated fatty acids) might improve psychological health via antioxidant action and inflammatory responses, which were consistent with precious and our studies that proper intake of fish was beneficial to mental health [26-29]. But part of studies believed that dietary intake of omega- 3 fatty acids showed no association with low mood level
[30]. These conflicting findings probably due to the different dietary consumption levels of omega- 3 fatty acids employed in different studies (ranging from $9.6 \mathrm{~g} /$ day to $2.2 \mathrm{~g} /$ day $[30,31])$ and the lack of distinction between intake of white versus fatty fish, which have varying contents of fatty acids $(0.48 \mathrm{~g} / 100 \mathrm{~g}$ in white fish (cod) to $5.33 \mathrm{~g} / 100 \mathrm{~g}$ in fatty fish (mackerel) [32].

Conversely, frying can promote to generate the transfatty acids, and these substances accumulate in the body to increase plasma levels of inflammatory cytokines, that is, C-reactive protein, TNF- $\alpha$, IL- $1 \beta$ and IL- 6 , which increase inflammation, thereby increasing the risk of mental health [33, 34]. Our research also found that more frequent fried food consumption indicates higher mental stress. Higher consumption frequency of pickled or smoked food and meat in men and dessert in women were related to an increased risk of mental stress. Picked and smoked foods are classified as unhealthy food

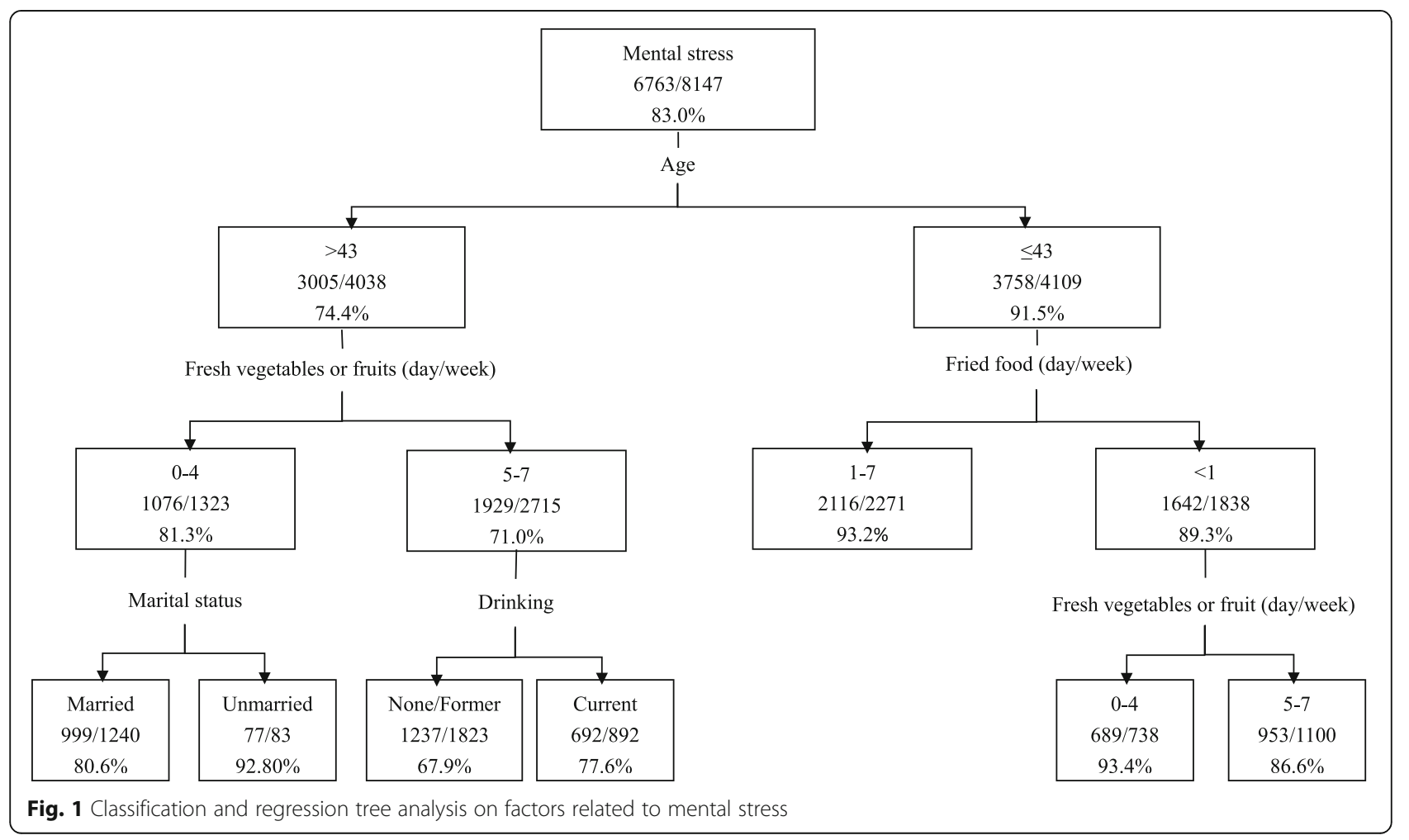




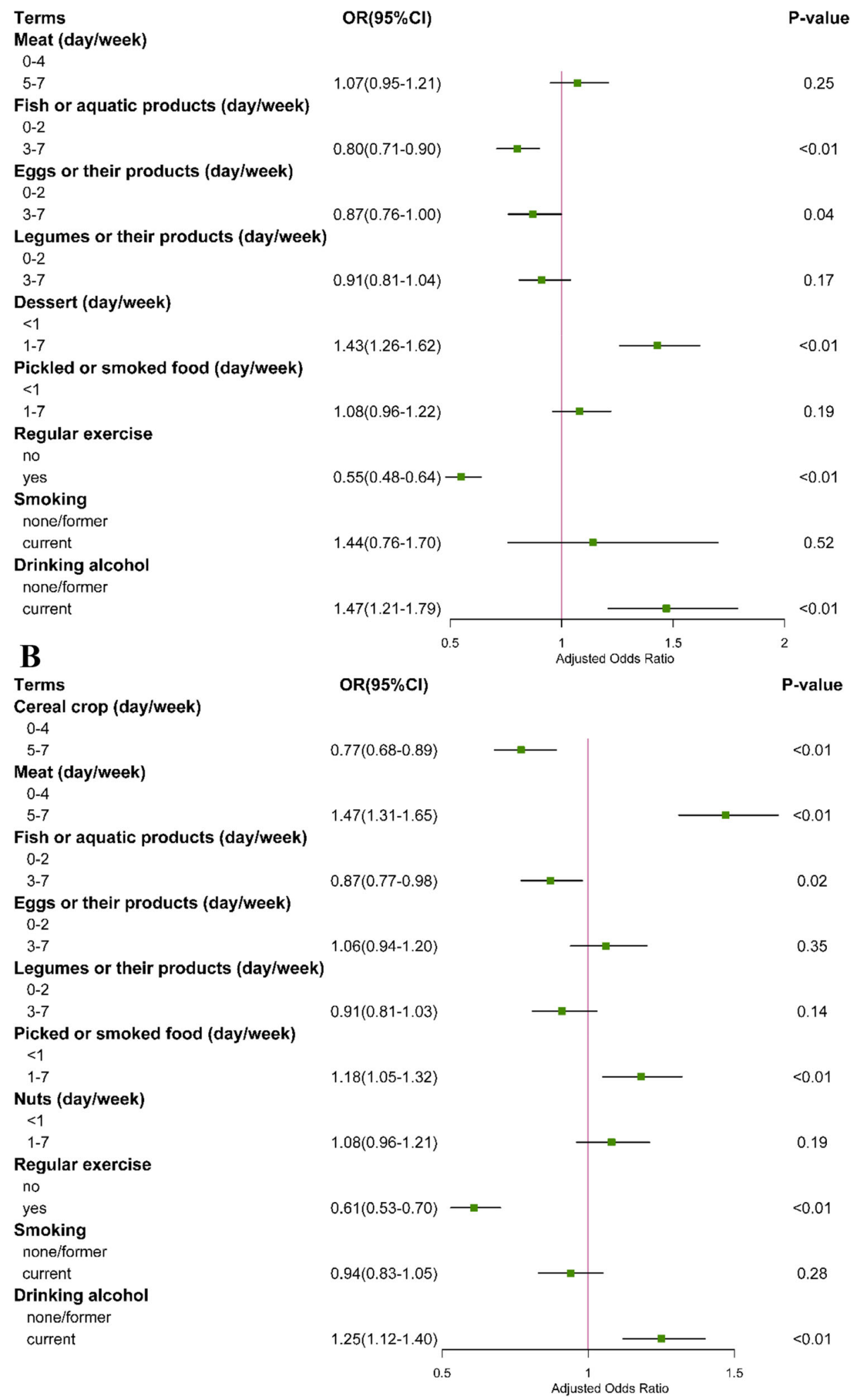

Fig. 2 Ordinal logistic regression analysis on factors related to mental stress. A Ordinal logistic regression analysis for the male. B Ordinal logistic regression analysis for the female 
because of the production way and increased unhealthy food intake could lead to perceived stress in young males $[35,36]$. Although the meat contains high protein and essential sources of minerals such as iron and zinc which could be vitally important for mood stabilization, it also constitutes a relevant source of arachidonic acid, saturated fatty acid and cholesterol which may increase the risk of psychological depression by aggravating inflammation [37-39]. Desserts are usually full of fat and energy which are linked to increased stress while leading to obesity in women [40]. At the same time, highstressed women seemed to prefer sweet, high-fat food more than did low-stressed women [41].

Exercise is associated with less subjective stress and buffers the effects of stress on physical and psychological health, a finding that has been observed in numerous populations from college students to older adults to veterans with post-traumatic stress disorder [42-44]. Our research also observed similar phenomenon that regular exercise exerts a positive effect on mental stress. However, not all studies found an association between stress and physical activity. The inconsistent results may be related to the differences in the methods of stress measurement, time duration or exercise intensity threshold between different studies.

Interestingly, the interaction between drinking alcohol condition and mental stress was bidirectional. Concretely, our data indicated that people who drank alcohol currently or drank more years (shown in supplementary table) had a higher probability of experiencing mental stress. And whether in cross-sectional or cohort researches, many researchers had founded that people with poor mental health were more possible to consume alcohol [45-47]. The alcohol could arouse the hypothalamic pituitary adrenal (HPA) axis and the glucocorticoid released from the end of this shaft would enter the circulation and thus activating the body's stress response systems [48]. The effect of alcohol on generation and neurotransmission of dopamine also can not be ignored in mental stress development $[49,50]$.

Nevertheless, drinking alcohol $\geq 30 \mathrm{~g}$ per day in females had positive something with mental stress (shown in supplementary table), consistent with some studies which suggested that alcohol has anxietyreducing properties and can relieve stress $[49,51]$. Hence, the link between drinking alcohol and mental stress seems complex and requires to be elucidated in more detailed and specific researches. And nicotine, as the major psychoactive component, has antidepressant and anxiolytic activity in both animals and humans [52, 53], which explained the fact that the negative relationship high smoking and mental stress for males to some extent.

\section{Limitations and future directions}

Our study had several limitations. First of all, our research was based on the data collected by the participants' physical examination, which, as auxiliary data, has some limitations in providing complete information. For example, this data didn't have information on extraneous factors such as weight, height, the demand of losing weight, the participants' dietary control and exercise needs varied greatly among individuals, especially those were obese. Hence, the integrity of the data might be relatively poor. Second, the food consumption, physical exercise condition and mental stress assessment were all based on self-report, which may be affected by recalling bias. In addition, food frequency assessment was not specifically quantified, which might increase unmeasured variation, reduce precision and possibly also affects validity of the measurement. Finally, given the crosssectional nature of the study, we were not able to assess the causality between food intake, physical exercises and mental stress. Therefore, further studies is still needed to verify the relationship between the consumption of food, physical exercise condition and mental stress via more specific and objective questionnaires and longitudinal data to confirm our results.

\section{Conclusions}

By a large sample survey, our study demonstrated that both the frequency of some food consumption and physical exercise condition were associated with mental health and affected the degree of stress in Chinese. Corresponding lifestyle changes may have a positive effect on reducing mental stress and improving the fitness level. However, further targeted longitudinal studies are needed to examine the causal association between mental stress and lifestyle, facilitating a better understanding of the pathways through which these variables are related.

\section{Supplementary Information}

The online version contains supplementary material available at https://doi. org/10.1186/s12889-021-11189-7.

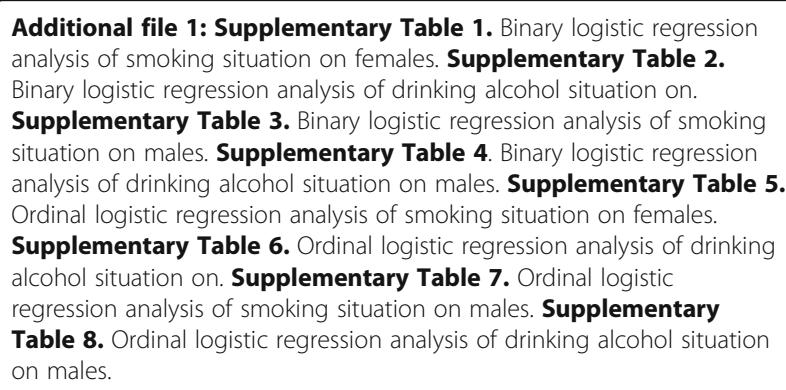




\section{Authors' contributions}

Xiaona Li, Jianming Wang and Qun Zhang participated in the study design. Xiaona Li, Qin Pei, Wen Guo, Jing Lu and Wenfang Zhu were involved in the conduct of the study and data collection. Xiaona Li and Dan Tian made contributions to the data analysis and interpretation of the results. Dan Tian, Jianming Wang and Qun Zhang wrote and modified the manuscript and prepared the tables and figures. All authors. Gave final approval of the version to be published; have agreed on the journal to which the article has been submitted; and agreed to be accountable for all aspects of the work.

\section{Funding}

This study was funded by the Natural Science Foundation of the Jiangsu Higher Education Institutions of China (19KJB320010), Social Development Project of Jiangsu Province (BE2016787), Jiangsu Province Health and Family Planning Research Project (H2017019), and Priority Academic Program Development of Jiangsu Higher Education Institutions (PAPD). The funding agencies had no role in the study design, data collection, analysis, decision to publish, or preparation of the manuscript.

\section{Availability of data and materials}

The datasets used and/or analyzed for the current study are available from the corresponding author on reasonable request.

\section{Declarations}

\section{Ethics approval and consent to participate}

This study was approved by the Ethics Committee of the First Affiliated Hospital of Nanjing Medical University (No.2018-SR-175). Written informed consent was obtained from study participants. The study was conducted in accordance with the Declaration of Helsinki.

\section{Consent for publication}

Not applicable.

\section{Competing interests}

The authors declare no conflict of interest.

\section{Author details}

${ }^{1}$ Health Management Center, The First Affiliated Hospital with Nanjing Medical University, Nanjing 210029, China. ${ }^{2}$ Department of Health Management, School of Public Health, Center for Global Health, Nanjing Medical University, Nanjing 211166, China. ${ }^{3}$ Department of Epidemiology, School of Public Health, Center for Global Health, Nanjing Medical University, Nanjing 211166, China.

\section{Received: 31 December 2020 Accepted: 1 June 2021} Published online: 14 June 2021

\section{References}

1. Navinés R, Martín-Santos R, Olivé V, Valdés M. Work-related stress: implications for physical and mental health. Med Clin. 2016;146(8):359-66. https://doi.org/10.1016/j.medcli.2015.11.023.

2. Marin MF, Lord C, Andrews J, Juster RP, Sindi S, Arsenault-Lapierre G, et al. Chronic stress, cognitive functioning and mental health. Neurobiol Learn Mem. 2011;96(4):583-95. https://doi.org/10.1016/j.nlm.2011.02.016.

3. Smeets T, Wolf OT, Giesbrecht T, Sijstermans K, Telgen S, Joëls M. Stress selectively and lastingly promotes learning of context-related high arousing information. Psychoneuroendocrinology. 2009;34(8):1152-61. https://doi. org/10.1016/j.psyneuen.2009.03.001.

4. Yang $L$, Zhao $Y$, Wang $Y$, Liu L, Zhang $X$, Li B, et al. The effects of psychological stress on depression. Curr Neuropharmacol. 2015;13(4):494504. https://doi.org/10.2174/1570159X1304150831150507.

5. Leone SS, Wessely S, Huibers MJ, Knottnerus JA, Kant I. Two sides of the same coin? On the history and phenomenology of chronic fatigue and burnout. Psychol Health. 2011;26(4):449-64. https://doi.org/10.1080/0887044 0903494191.

6. Prior A, Fenger-Grøn M, Larsen KK, Larsen FB, Robinson KM, Nielsen MG, et al. The association between perceived stress and mortality among people with multimorbidity: a prospective population-based cohort study. Am J Epidemiol. 2016;184(3):199-210. https://doi.org/10.1093/aje/kwv324.
7. McEwen BS. Biomarkers for assessing population and individual health and disease related to stress and adaptation. Metab Clin Exp. 2015;64(3 Suppl 1): S2-s10. https://doi.org/10.1016/j.metabol.2014.10.029.

8. Rehm J, Shield KD. Global burden of disease and the impact of mental and addictive disorders. Curr Psychiat Rep. 2019;21(2):10. https://doi.org/10.1007/ s11920-019-0997-0.

9. Głąbska D, Guzek D, Groele B, Gutkowska K. Fruit and vegetable intake and mental health in adults: a systematic review. Nutrients. 2020;12(1):115. https://doi.org/10.3390/nu12010115.

10. Goyal M, Singh S, Sibinga EM, Gould NF, Rowland-Seymour A, Sharma R, et al. Meditation programs for psychological stress and well-being: a systematic review and meta-analysis. JAMA Intern Med. 2014;174(3):357-68. https://doi.org/10.1001/jamainternmed.2013.13018.

11. Yang B, Qin QZ, Han LL, Lin J, Chen Y. Spa therapy (balneotherapy) relieves mental stress, sleep disorder, and general health problems in sub-healthy people. Int J Biometeorol. 2018;62(2):261-72. https://doi.org/10.1007/s00484017-1447-5.

12. Lin SL, Huang CY, Shiu SP, Yeh SH. Effects of yoga on stress, stress adaption, and heart rate variability among mental health professionals--a randomized controlled trial. Worldviews Evid-Based Nurs. 2015;12(4):236-45. https://doi. org/10.1111/wvn.12097.

13. Schrieks IC, Joosten MM, Klöpping-Ketelaars WA, Witkamp RF, Hendriks HF. Moderate alcohol consumption after a mental stressor attenuates the endocrine stress response. Alcohol. 2016;57:29-34. https://doi.org/10.1016/j.a Icohol.2016.10.006

14. Yoshikawa E, Nishi D, Matsuoka YJ. Association between frequency of fried food consumption and resilience to depression in Japanese company workers: a cross-sectional study. Lipids Health Dis. 2016;15(1):156. https://doi. org/10.1186/s12944-016-0331-3.

15. Nguyen B, Ding D, Mihrshahi S. Fruit and vegetable consumption and psychological distress: cross-sectional and longitudinal analyses based on a large Australian sample. BMJ Open. 2017;7(3):e014201. https://doi.org/10.113 6/bmjopen-2016-014201.

16. Paolucci EM, Loukov D, Bowdish DME, Heisz JJ. Exercise reduces depression and inflammation but intensity matters. Biol Psychol. 2018;133:79-84. https://doi.org/10.1016/j.biopsycho.2018.01.015.

17. McEwen BS. Stress, adaptation, and disease. Allostasis and allostatic load. Ann N Y Acad Sci. 1998;840(1):33-44. https://doi.org/10.1111/j.1749-6632.1998.tb09546.x.

18. Yada $H$, Abe H, Omori $H$, Matsuo $H$, Masaki $O$, Ishida $Y$, et al. Differences in job stress experienced by female and male Japanese psychiatric nurses. Int J Ment Health Nurs. 2014;23(5):468-76. https://doi.org/10.1111/inm.12080.

19. Redondo-Flórez L, Tornero-Aguilera JF, Ramos-Campo DJ, Clemente-Suárez VJ. Gender differences in stress- and burnout-related factors of university professors. Biomed Res Int. 2020;2020:6687358. https://doi.org/10.1155/2020/ 6687358.

20. Gehlich KH, Beller J, Lange-Asschenfeldt B, Köcher W, Meinke MC, Lademann J. Consumption of fruits and vegetables: improved physical health, mental health, physical functioning and cognitive health in older adults from 11 European countries. Aging Ment Health. 2020;24(4):634-41. https://doi.org/10.1080/13607863.2019.1571011.

21. Saghafian F, Malmir H, Saneei P, Keshteli AH, Hosseinzadeh-Attar MJ, Afshar $\mathrm{H}$, et al. Consumption of fruit and vegetables in relation with psychological disorders in Iranian adults. Eur J Nutr. 2018;57(6):2295-306. https://doi.org/1 0.1007/s00394-018-1652-y.

22. Tuck NJ, Farrow C, Thomas JM. Assessing the effects of vegetable consumption on the psychological health of healthy adults: a systematic review of prospective research. Am J Clin Nutr. 2019;110(1):196-211. https:// doi.org/10.1093/ajcn/nqz080.

23. Boehm JK, Soo J, Zevon ES, Chen Y, Kim ES, Kubzansky LD. Longitudinal associations between psychological well-being and the consumption of fruits and vegetables. Health Psychol. 2018;37(10):959-67. https:/doi.org/10.1037/hea0000643.

24. Gehlich KH, Beller J, Lange-Asschenfeldt B, Köcher W, Meinke MC, Lademann J. Fruit and vegetable consumption is associated with improved mental and cognitive health in older adults from non-Western developing countries. Public Health Nutr. 2019;22(4):689-96. https://doi.org/10.1017/S1368980018002525.

25. Cheng HY, Shi YX, Yu FN, Zhao HZ, Zhang JH, Song M. Association between vegetables and fruits consumption and depressive symptoms in a middleaged Chinese population: an observational study. Medicine. 2019;98(18): e15374. https://doi.org/10.1097/MD.0000000000015374.

26. Sanchez-Villegas A, Henríquez P, Figueiras A, Ortuño F, Lahortiga F, Martínez-González MA. Long chain omega-3 fatty acids intake, fish 
consumption and mental disorders in the SUN cohort study. Eur J Nutr. 2007;46(6):337-46. https://doi.org/10.1007/s00394-007-0671-X.

27. Silvers KM, Scott KM. Fish consumption and self-reported physical and mental health status. Public Health Nutr. 2002;5(3):427-31. https://doi.org/1 0.1079/PHN2001308

28. Smith KJ, Sanderson K, McNaughton SA, Gall SL, Dwyer T, Venn AJ. Longitudinal associations between fish consumption and depression in young adults. Am J Epidemiol. 2014;179(10):1228-35. https//doi.org/10.1093/aje/kwu050.

29. Song C, Shieh CH, Wu YS, Kalueff A, Gaikwad S, Su KP. The role of omega-3 polyunsaturated fatty acids eicosapentaenoic and docosahexaenoic acids in the treatment of major depression and Alzheimer's disease: acting separately or synergistically? Prog Lipid Res. 2016;62:41-54. https://doi.org/1 0.1016/j.plipres.2015.12.003.

30. Stoll AL, Severus WE, Freeman MP, Rueter S, Zboyan HA, Diamond E, et al. Omega 3 fatty acids in bipolar disorder: a preliminary double-blind, placebo-controlled trial. Arch Gen Psychiatry. 1999;56(5):407-12. https:/doi. org/10.1001/archpsyc.56.5.407.

31. Hakkarainen R, Partonen T, Haukka J, Virtamo J, Albanes D, Lönnqvist J. Is low dietary intake of omega-3 fatty acids associated with depression? Am J Psychiatry. 2004;161(3):567-9. https://doi.org/10.1176/appi.ajp.161.3.567.

32. Fatty Acids: Supplement to McCance \& Widdowson's the composition of foods Cambrigde: Royal Society of Chemistry/Ministry of Agriculture, Fisheries and Food; 1999.

33. Baer DJ, Judd J, Clevidence BA, Tracy RP. Dietary fatty acids affect plasma markers of inflammation in healthy men fed controlled diets: a randomized crossover study. Am J Clin Nutr. 2004;79(6):969-73. https://doi.org/10.1093/ajcn/79.6.969.

34. Han SN, Leka LS, Lichtenstein AH, Ausman LM, Schaefer EJ, Meydani SN. Effect of hydrogenated and saturated, relative to polyunsaturated, fat on immune and inflammatory responses of adults with moderate hypercholesterolemia. J Lipid Res. 2002;43(3):445-52. https:/doi.org/10.1016/50022-2275(20)30151-6.

35. Tariq S, Tariq S, Tariq S. Association of perceived stress with healthy and unhealthy food consumption among teenagers. JPMA J Pak Med Assoc. 2019;69(12):1817-21. https://doi.org/10.5455/JPMA.302642278.

36. Yu H, Xu Q, Xiong W, Liu Z, Cai L, He F. Association of pickled food, fired food and smoked food combined with smoking and alcohol drinking with lung cancer: a case-control study. Wei Sheng Yan Jiu. 2019;48(6):925-31.

37. Boada LD, Henríquez-Hernández LA, Luzardo OP. The impact of red and processed meat consumption on cancer and other health outcomes: epidemiological evidences. Food Chem Toxicol. 2016;92:236-44. https://doi. org/10.1016/j.fct.2016.04.008.

38. Rohrmann S, Linseisen J. Processed meat: the real villain? Proc Nutr Soc. 2016;75(3):233-41. https://doi.org/10.1017/S0029665115004255.

39. Scollan ND, Price EM, Morgan SA, Huws SA, Shingfield KJ. Can we improve the nutritional quality of meat? Proc Nutr Soc. 2017;76(4):603-18. https://doi. org/10.1017/S0029665117001112

40. Oliver G, Wardle J, Gibson EL. Stress and food choice: a laboratory study. Psychosom Med. 2000;62(6):853-65. https://doi.org/10.1097/00006842-2 00011000-00016.

41. Habhab S, Sheldon JP, Loeb RC. The relationship between stress, dietary restraint, and food preferences in women. Appetite. 2009;52(2):437-44. https://doi.org/10.1016/j.appet.2008.12.006

42. Buckley TC, Mozley SL, Bedard MA, Dewulf AC, Greif J. Preventive health behaviors, health-risk behaviors, physical morbidity, and health-related role functioning impairment in veterans with post-traumatic stress disorder. Mil Med. 2004;169(7):536-40. https://doi.org/10.7205/MILMED.169.7.536.

43. McHugh JE, Lawlor BA. Exercise and social support are associated with psychological distress outcomes in a population of community-dwelling older adults. J Health Psychol. 2012;17(6):833-44. https://doi.org/10.1177/1359105311423 861.

44. Song X, Ding N, Jiang N, Li H, Wen D. Time use in out-of-class activities and its association with self-efficacy and perceived stress: data from second-year medical students in China. Medical education online. 2020;25(1):1759868. https://doi.org/10.1080/10872981.2020.1759868.

45. Goodwin L, Norton S, Fear NT, Jones M, Hull L, Wessely S, et al. Trajectories of alcohol use in the UK military and associations with mental health. Addict Behav. 2017;75:130-7. https://doi.org/10.1016/j.addbeh.2017.07.010.

46. Obadeji A, Oluwole LO, Dada MU, Oshatimi MA. Alcohol use and psychological wellbeing of health workers in a Nigerian hospital: an exploratory study. Malawi medical journal : the journal of Medical Association of Malawi. 2018;30(1):31-6. https://doi.org/10.4314/mmj.v30i1.7.
47. Degenhardt L, Saha S, Lim CCW, Aguilar-Gaxiola S, Al-Hamzawi A, Alonso J, et al. The associations between psychotic experiences and substance use and substance use disorders: findings from the World Health Organization World Mental Health surveys. Addiction (Abingdon, England). 2018;113(5):924-34.

48. Sillaber I, Henniger MS. Stress and alcohol drinking. Ann Med. 2004;36(8): 596-605. https://doi.org/10.1080/07853890410018862.

49. Becker HC. Influence of stress associated with chronic alcohol exposure on drinking. Neuropharmacology. 2017;122:115-26. https://doi.org/10.1016/j. neuropharm.2017.04.028.

50. Soder HE, Webber TA, Bornovalova MA, Park JY, Potts GF. A test of dopamine hyper- and hyposensitivity in alcohol use. Addict Behav. 2019;90: 395-401. https://doi.org/10.1016/j.addbeh.2018.12.002.

51. Abrams K, Cieslowski K, Johnson S, Krimmel S, La Rosa GB, Barton K, et al. The effects of alcohol on heartbeat perception: implications for anxiety. Addict Behav. 2018;79:151-8. https://doi.org/10.1016/j.addbeh.2017.12.023.

52. Rorabaugh BR, Sprague L, Norman H, Seeley SL, D'Souza MS. Regulator of G protein signaling 2 differentially regulates nicotine-induced anxiolytic- and antidepressant-like effects in mice. Eur J Neurosci. 2018;48(5):2110-7. https:// doi.org/10.1111/ejn.14100.

53. Zarrindast MR, Khakpai F. The modulatory role of nicotine on cognitive and non-cognitive functions. Brain Res. 2019;1710:92-101. https://doi.org/10.101 6/j.brainres.2018.12.002.

\section{Publisher's Note}

Springer Nature remains neutral with regard to jurisdictional claims in published maps and institutional affiliations.
Ready to submit your research? Choose BMC and benefit from:

- fast, convenient online submission

- thorough peer review by experienced researchers in your field

- rapid publication on acceptance

- support for research data, including large and complex data types

- gold Open Access which fosters wider collaboration and increased citations

- maximum visibility for your research: over $100 \mathrm{M}$ website views per year

At $\mathrm{BMC}$, research is always in progress.

Learn more biomedcentral.com/submissions 